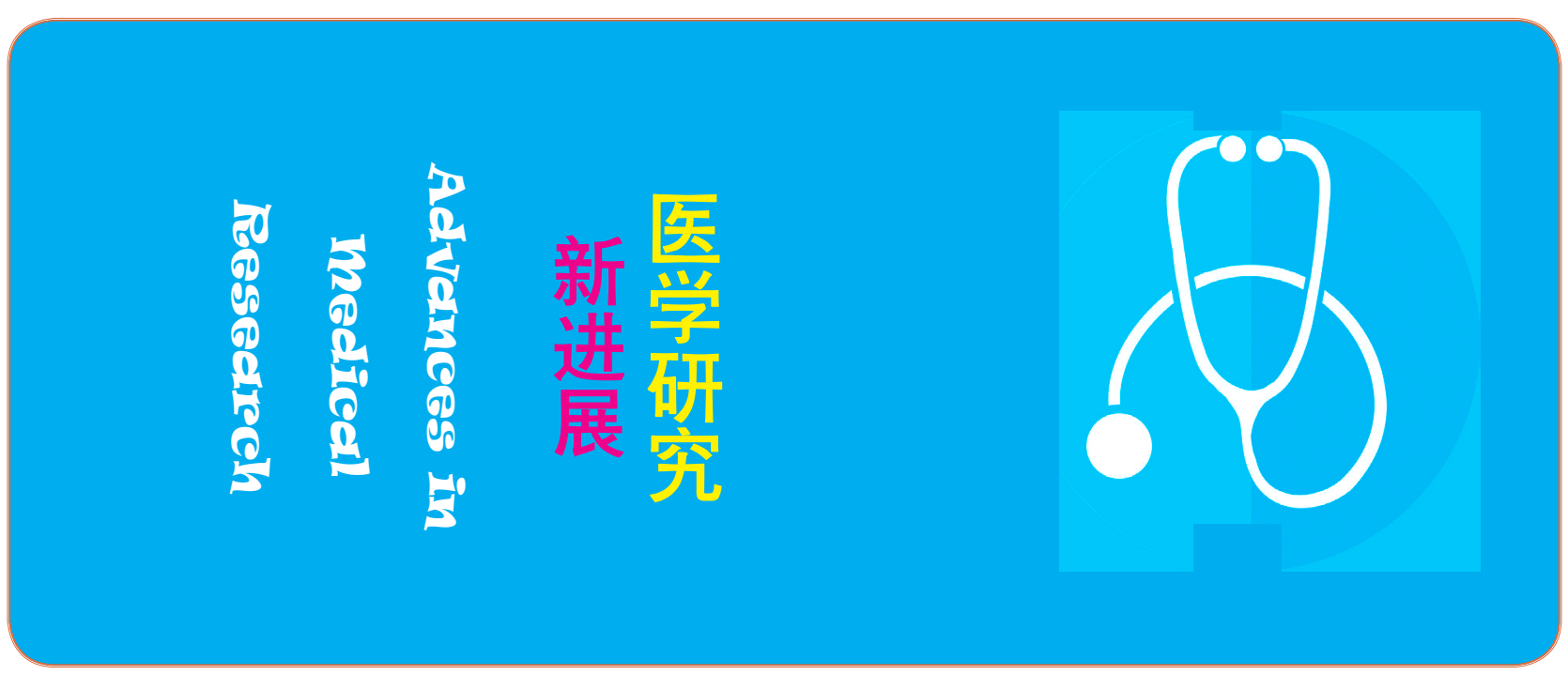

\section{科学家发现强大的 止痛药}

\section{Mike Wang}

University of Illinois at Urbana-Champaign

美国德克萨斯大学的科学 家们宣布发现一种强大的止痛 药- - UKH-1114, 一种针对前 所未知的疼痛途径止痛的化合 物, 能够以比目前市场上常见的 加巴喷丁 (Gabapentin, 一种慢 性疼痛止痛剂) 更小的剂量且更 长的止痛时间来有效缓解小鼠的 神经性疼痛。如果该药物的安全 性能够被证明, 那么它将开启非 阿片药物治疗神经性疼痛的新疗 法, 成为解决阿片类药物滥用的 有效工具。

神经性疼痛或慢性疼痛主 要是由于中枢神经系统的神经受 损而引起的，除此之外，也可能 是化疗、糖尿病、或大脑和脊髓
损伤引起的。目前，近三成的美 国人患有慢性疼痛, 而最有效的 止痛药就是阿片类药物, 这是一 类致人成滤、且需要不断加大剂 量才能维持疗效的止疼药。据美 国国家药物滥用研究所介绍, 美 国约有 200 万人对阿片类药物成 瘾。能够替代阿片类药物的止痛 剂都有自己的缺陷, 例如加巴喷 丁, 可能导致某些个体的认知障 碍。

德克萨斯大学达拉斯分校神 经科学和慢性疼痛领域的专家测 试了 UKH-1114 对神经损伤的小 鼠的治疗效果, 发现该药物缓解 疼痛的效果与加巴喷丁一样, 但 使用剂量比加巴喷丁低得多 (六分
之一倍), 且其有效时间更长 (持 续多天, 4 到 6 小时每天)。这项 研究首次证明了西格玛 - 2 受体可 能是治疗神经性疼痛的靶点。其 实西格玛 -2 受体早在 25 年前就 被发现了, 但科学家们直到现在 才知道它的作用。

在 UKH-1114 进入市场之前, 科学家们仍有许多工作要做, 他 们需要更多的研究来证明该药物 的安全性、有效性、以及口服生 物利用度。与此同时, 科学家正 在从根本上了解激活西格玛 2 受 体是如何减轻神经性疼痛的。

尽管如此，小鼠模型的结果 已经极大的鼓舞了研究人员, 他 们认为这一发现将改善很多备受 慢性疼痛或阿片类药物成瘾困扰 的人们的生活质量。

\section{参考文献}

[1] Sahn JJ, Mejia GL, Ray PR, Martin SF, Price TJ. Sigma 2 Receptor/ Tmem97 Agonists Produce Long Lasting Antineuropathic Pain Effects in Mice. ACS Chem Neurosci, 2017;8(8):1801-1811. doi:10.1021/ acschemneuro.7b00200. 